part of an arcus senilis, with exactly the same sharp line of demarcation at the limbal edge and the same clear zone of cornea. A series of blebs thus formed, growing more and more prominent, till they became confluent and formed a band-like strip, broadening to about $2 \mathrm{~mm}$. The whole process only occupied a period of about two or three minutes, when the bubbles burst and discharged a small quantity of liquid blood. Two days later there was no trace left. Probably an extravasation of blood took place just beyond the limbal vessels and wedged its way beneath the corneal epithelium, and, after elevating this off Bowman's membrane, finally burst it. The situation of this haematoma was interesting, as well as the clear zone of cornea, and doubtless has its anatomical reasons. But in spite of the similarity of position we do not think that there can be any true analogy between the anatomical causes of this appearance and those of arcus senilis. Arcus senilis is a degeneration, probably of a modified fat, occurring at the peripheral edge of Bowman's membrane, which does not quite reach the limbus (Collins and Mayou). It is likely that the haematoma here described formed just where the limbal circulation leaves its conjunctival support and pours its lymph into the cornea. The tissues and vessels being in a degenerate and friable condition in these regions in absolute glaucoma, they broke along the zone where they lose their conjunctival support, in a sharply defined line. We offer this as a partial explanation of what occurred.

\title{
ANNOTATION
}

\section{Ophthalmology in Fiction}

It must be conceded that the whole tone of the doctor in fiction has been immeasurably raised during the last century. Smollett, himself a medical man, draws, in Roderick Random, vile pictures of the general practitioners of his day, Messrs. Crabb and Potion, compounds of the charlatan and the buffoon; while his only educated physician that occurs to us is the one whom Perigrine Pickle met in Paris, who is usually regarded as a caricature of Dr. Akenside. How great a part the medical profession plays in fiction will be recognized by all who have thought about the matter; but ophthalmology and the oculist, being of comparatively recent development, do not find much place in English literature before the middle of the last century. Lytton, in Night and Morning, tells us of an interesting case of family strabismus, where Beaufort, 
meeting Mrs. Morton, towards the end of the book, asks after her brother and is informed that he has retired from his business and has been succeeded by his son-in-law, Mr. Plimmins. Beaufort asks which of the young ladies Plimmins had married and is answered" thus : "Jane, she had a sad squint. Tom, there is nothing to laugh at; we are as God made us-handsome is as handsome does; she has had three little 'uns." "Do they squint too," asks Beaufort. This time Mrs. Morton administered no reproof, but replied pensively. "Natur' is very mysterious; they all squint."

Dickens, in drawing one of his most famous characters, $\mathrm{Mr}$. Squeers, gave him only one eye. Stevenson, a sick man all his life, has an occasional jeer at the medical profession; none more amusing than that in The Wrong Box, where among other details occurs : "the old gentleman who had passed his life wandering in a tweed suit on the Continent of Europe ; and years of Galignani's Messenger having at length undermined his eyesight, he suddenly remembered the rivers of Assyria and came to London to consult an oculist. From the Oculist to the Dentist and from both to the Physician, the step appears inevitable; presently he was in the hands of Sir Faraday, robed in ventilating cloth and sent to Bournemouth ; and to that domineering Baronet (who was his only friend upon his native soil) he was now returning to report."

$\mathrm{Mr}$. Lemuel Gulliver noted, not in so many words, that the inhabitants of Lilliput were myopic. His own eyes were weak; while a novel use for his glasses was when he employed them to ward off the darts that were shot at him.

The most atrocious specimen of ophthalmology in English literature is probably to be found in Poor Miss Finch, by Wilkie Collins. The lady's traumatic cataract, the lover's epileptiform attacks which were treated with silver nitrate pills; the argyria resulting therefrom; the German oculist who spoke very bad English and performed wonderful operations in spite of the adverse opinion expressed by his English colleague; are these not all written in the book in question?

One of the nicest bits of ophthalmology in fiction is found in Tristram Shandy; the pretended foreign body in Widow Wadman's eye. ' 'I protest, Madam,' said my Uncle Toby, 'I can see nothing whatever in your eye.' 'It is not in the white,' said Mrs. Wadman."

We pass over those examples of ophthalmology that occur in modern works of fiction, such as in The Light that Failed, by Kipling; The Four Feathers, by Mason; and in Sonia; and will only express the hope that, in future, if an author wishes to introduce an oculist in his works, he will support home industries, instead of the more favoured Teutonic operators. 